\title{
Painajakogemusest rääkimine internetifoorumites ${ }^{1}$
}

\begin{abstract}
Reet Hiiemäe
Teesid: Artikli keskmes on painajakogemusest rääkimine internetifoorumites. Vaatlen, kuidas sellisest kogemusest räägivad inimesed, kes üldjuhul ei ole järjepideva painajapärimuse aktiivsed kandjad, kuidas ja millistele allikatele tuginedes nad oma kogemusi defineerivad ja tõlgendavad ning millised dünaamikad ilmnevad ideeliste vaidlusküsimuste lahendamisel. Üks artikli eesmärke on välja selgitada, kas vaatamata sellele, et foorumiaruteludes osalejad on võrdlemisi juhuslikud ja väga erineva taustaga, on õigustatud painajast rääkivate foorumikasutajate käsitamine pärimuskogukonnana, mille koostoimes verbaliseeritakse ja tõlgendatakse üksikisiku kogemus olemasoleva traditsiooniga kokkusobivaks. Ühtlasi võrdlen foorumitest pärinevat materjali vanemate painajatekstidega, et tuua välja tänapäeva materjalile eriomased jooned.
\end{abstract}

Märksõnad: internetifolkloor, jutustamine, painaja, pärimuskogukond, usund

\section{Sissejuhatuseks}

Erinevates kultuurides ja erinevatel aegadel on defineeritud painajafenomeni erinevalt ja lähtutud selle tõlgendamisel mitmetest uskumussüsteemidest. Põhilised sümptomid, mida painajaga seostatakse, on aga ajas jäänud samaks: iseloomulik on uneajal (või vahetult enne või pärast und) kogetav survetunne, millega kaasneb suutmatus liigutada, hingamisraskused ja intensiivne hirmutunne. Vanemas eesti pärimuses (nagu ka teistes Euroopa kultuurides) ei ole painajasümptomite ilmnemist enamasti tajutud haigusena, vaid neid on eelkõige arvatud tingituks pahatahtlikust nõidusest. Harvemini (umbes sajalkonnal korral) seletavad eesti folklooritekstid painaja ilmumist vastamata armastusega, mis sunnib inimest oma armastuse objekti painaja kujul külastama. On ka mõnikümmend sellist arhiiviteksti, mille kohaselt inimene ei käi luupainajaks omal soovil, vaid mõne kurja kaasinimese poolt pealepandud nõiduse tõttu. Pärimustekstide kohaselt kaasneb magajal sümptomite avaldu- 
misega tavaliselt tajumus, nagu roniks talle peale mingi inim-või loomakujuline kogu, mis põhjustabki survetunde.

Nähtus ei ole kaotanud oma aktuaalsust ka moodsas maailmas ja paljud inimesed näevad endist viisi vaeva vastavate kogemuste mõtestamisega. Isegi folkloristide ja muude humanitaarteadlaste hulgas ei valitse üksmeelt painajakogemuste põhjuste osas. Mitmed autorid (nt Owen Davies 2003; Robert Ness 1978) on arvamusel, et neid kogemusi põhjustab unehalvatus, kuna see haigus võib tekitada ajutist halvatusseisundit, millega kaasnevad hallutsinatsioonilaadsed tajumused, pealegi on unehalvatus meditsiiniliste uuringute kohaselt võrdlemisi levinud - seda esineb 20-45 protsendil elanikkonnast (vrd Davies 2003: 182). Ilmunud on ka mõned painajakogemuse psühhoanalüütilised tõlgendused, milles nähakse nähtuse põhjusena neurootiliselt allasurutud seksuaalsust (nt Jones 1931). Religiooniteadlane David Hufford (1989, 2005) on seisukohal, et üleloomuliku rünnaku jutud põhinevad reaalsetel kogemustel, ent need kogemused võivad edasirääkimise käigus kohaneda olemasoleva jutustamistraditsiooniga.

Minu eesmärk ei ole välja selgitada, kas jutustajate painajakogemused on üleloomulikud või meditsiinilised, samuti ei püüa ma jälile jõuda nende tegelikele põhjustele. Keskendun artiklis sellele, kuidas sellest nähtusest räägivad internetifoorumites suhtlevad inimesed, kes üldjuhul ei ole järjepideva painajapärimuse aktiivsed kandjad; vaatlen, kuidas ja millistele allikatele tuginedes nad oma kogemusi defineerivad ja tõlgendavad ning millised dünaamikad ilmnevad ideeliste vaidlusküsimuste lahendamisel. Üks artikli eesmärke on välja selgitada, kas vaatamata sellele, et foorumiaruteludes osalejad on võrdlemisi juhuslikud ja väga erineva taustaga inimesed, on õigustatud painajast rääkivate foorumikasutajate käsitamine pärimuskogukonnana, mille koostoimes verbaliseeritakse ja tõlgendatakse üksikisiku kogemus olemasoleva traditsiooniga kokkusobivaks. Ühtlasi võrdlen foorumitest pärinevat materjali vanemate painajatekstidega, et tuua välja tänapäeva materjalile eriomased jooned. Artikkel põhineb rohkem kui kolmesajal võimalikult erinevatest internetifoorumitest kogutud tekstil ja nende tekstide kommentaaridel (tekstid pärinevad aastatest 2009-2014). Võrdlusmaterjalina on kasutatud Eesti Rahvaluule Arhiivis leiduvaid vanemast folkloorist pärit painajakirjeldusi (see mahukas materjalikorpus hõlmab mitu tuhat teksti, mis on valdavalt kogutud ajavahemikus 1880. aastatest kuni 20. sajandi esimese pooleni). 


\section{Foorum kui pärimuskogukond: teoreetilisi ja metodoloogilisi lähtekohti}

Tänapäeva Eesti ühiskonnas puuduvad üldtunnustatud juhised painajakogemustega toimetulekuks, selline teave ei kuulu automaatselt üldkultuuriliste teadmiste hulka. Kui üldse, siis arutatakse selliseid kogemusi väiksemas sõprade või pereliikmete ringis. Nagu märgitakse ka paljudes foorumitekstides, kardavad inimesed oma painajakogemustest avalikult rääkida, kuna on oht, et rääkijaid ei võeta tõsiselt või peetakse koguni vaimses mõttes ebaadekvaatseks, näiteks tunnistab üks kirjutaja:

Mäletan, kui jube mul endal oli 6htuti magama minna ja abi ka nagu kelleltki ei saanud, ma ei julgenud kellelegi rääkidagi. arvasin, et peetakse imelikuks kah veel, kui räägin (naistekas.delfi.ee/foorum, kasutaja: to Õdne elu, mai 2010).

Nimetatud hirmud on ilmselgelt ka üks põhjus, miks sellised postitused on enamasti anonüümsed või tehtud kasutajanimede alt, mis ei võimalda seostamist reaalse inimesega. Olgugi, et kõik tsiteeritud foorumipostitused on pärit avalikest internetifoorumitest ja seega kõigile nähtavad, ei olnud need sinna kirjutatud arvestusega, et neid kasutatakse uurimistöö materjalina - seetõttu asendasin minu arvates pisutki mõnele konkreetsele isikule viitavad kasutajanimed artiklis lühendkodeeringutega.

Tekstid on kogutud passiivse vaatluse teel, ilma omalt poolt vestluskulgu suunamata, kuna olen ühel meelel autoritega, kes leiavad, et foorumiarutelude sekkumatu vaatlemine võimaldab osa saada autentsest pärimuskommunikatsioonist, mis on sarnane folkloori jälgimisega igas muus algupärases kasutuskeskkonnas (vrd Kõiva \& Vesik 2009: 98).

Samas pole isikuid, kellel on olnud painajana tõlgendatud läbielamisi, sugugi vähe. Folklorist Owen Daviesi hinnangul kogeb 5-20\% elanikkonnast jätkuvalt asju, mida võib defineerida painajakogemusena (Davies 2003: 182). Viisid, kuidas nendest kogemustest räägitakse, on aja jooksul mõnevõrra muutunud, kuid ilmselgelt vajatakse jätkuvalt võimalust nende verbaliseerimiseks. Paljudest foorumipostitustest nähtub, et internet ongi esimene koht, kust inimesed hakkavad oma painajakogemusele seletusi otsima ning kust vastav teave ja abivõtted tõepoolest hangitakse, nagu selgub ka järgmisest foorumitekstist:

Minul pole rohkem juhtunud [kui üks kord], aga peale seda lugesin internetist hästi palju luupainajate kohta ja usun, et kui ta järgmisel korral soovib tulla, siis olen temaks valmis (www.perekool.ee, anonüümne kasutaja, juuli 2012). 
Väärib märkimist, et üldfoorumite kasutajate puhul ei saa rääkida pärimuskogukonnast selle sõna klassikalises mõistes - kui mingite kindlate kultuuriliste tunnuste ja väärtuste poolest eristuvast inimrühmast. Ehk nagu retooriliselt küsib Barbara Kirschenblatt-Kimblett: "Mida me mõtleme terminite grupp ja kogukond all, kui lihtsalt võõrad inimesed maailma erinevates otstes arvuti taga istuvad ja sõnumeid vahetavad?" (1998: 284). Ka Lauri Honko väljendab samalaadseid kahtlusi: "Kas võib juhuslikult kokku sattunud inimeste väljendusi pidada folklooriks või kas mis tahes üsna abstraktne huvirühm võib toimida nagu liikmeskond?" ja leiab, et folkloori saab ikkagi seostada suhteliselt pikaaegsete rühmadega (Honko 1998).

Näiteks foorumi naistekas.delfi.ee/foorum sihtrühma peamise siduva lülina on vaadeldav ainult sugu (kuid samas ei välista see meessoost kasutajate olemasolu ja mitmed kasutajanimed viitavadki meessoost postitajatele), foorumi www.perekool.ee kasutajate ühistunnuseks on tõenäoliselt enamasti lapsevanemaks olemine või peatne selleks saamine, ent selle tunnuse põhjal ei saa teha mingeid järeldusi sealsete kasutajate painajapärimuse tundmise osas. Enamasti tõstatatakse painajateema foorumis seetõttu, et selline kogemus on tabanud teemaalgatajat esmakordselt ja tal puuduvad selle teema kohta teadmised, seega ei ole kasutajatel selles aspektis aktiivset ühist usundilist tausta. Painajateemalisi postitusi esitatakse üldiselt anonüümselt või sellise kasutajanime all, mis ei võimalda isikut tuvastada. Enamasti räägivad postitajad iseenda läbielatust, kuid mõnevõrra kirjeldatakse ka lähedaste inimeste (nt abikaasa, ema, sõbranna) kogemusi.

Teisalt on painaja kogejaid mitmeid, ja diskussiooni käigus viitavad teadjamad kasutajad olemasolevale usunditraditsioonile (nt new age kirjanduse, vanavanematelt või muudelt vanematelt sugulastelt kuuldud rahvajuttude, sõbrannadelt kuuldud teabe näol). Seega on siduv usundiline pärimustaust vähemalt häguste teadmiste näol aluspinnana olemas ja piisav selleks, et aidata valada üksikisikute erakordsed kogemused rohkem või vähem tüüpilisse vormi. Öelduga haakub Bruce McClellandi pärimuskogukonna ja folkloori kaasajastatud definitsioon, milles ta käsitleb folkloori kui "kommunikatiivset käitumist, mille üks peamisi omadusi on tõik, et see ei 'kuulu' konkreetsele isikule või grupile [---]; seda antakse teatud olukordades spontaanselt edasi ühelt isikult või isikuterühmalt teisele, ootamata selle eest enamasti mingit vastutasu. Kui see on edasi antud, allub see järgmise jutustaja tõekspidamistest lähtuvale modifitseerimisele" (McClelland 2000: 184).

Isegi ühe teemaalgatuse raames on vahel võimalik jälgida, kuidas vestluse edenedes lisanduvad elemendid, mida esmakirjelduses veel polnud, seda protsessi suunavad teiste foorumikasutajate hinnangud ja omapoolsed kogemusekirjeldused, homogeniseerides üksikisiku kogemuse narratiivset esitust. Seega saab foorumis arutatud painajakogemusi nimetada vaid tinglikult 
individuaalseteks, kuna need läbivad sotsiaalse valideerimise, mis lähtub nii diakroonilisest pärimusliinist (nt viited vanavanematelt kuuldule) kui ka sünkroonsest võrdlusest (foorumikaaslaste ütlused). Kuigi foorumis arutlejad ei kuulu klassikalises mõttes pärimuskogukonda, toimub painajalugude folkloriseerumisprotsess (ehk siis reaalkogemuse järk-järguline mugandamine traditsiooniga haakuvaks narratiiviks) mitmes mõttes samamoodi nagu näiteks vanemas külaühiskonnas. Pealegi selgub lähemal vaatlusel, et teatav kasutajate ühiste tunnuste alusel selekteerumine foorumites siiski toimub. Mitmed Delfi Naisteka foorumi (delfi.naistekas.ee/foorum) painajateemalised arutelud toimuvad alarubriigis Müstikanurgake, mis juba oma pealkirjaga mingil määral kategoriseerib kasutajad vastavalt nende huvile müstika vastu. Pealegi esineb viide painajale enamasti juba selleteemalise postituse pealkirjas, mistõttu inimestel, kes üldse niisuguse postituse avavad ja potentsiaalselt kommenteerivad, on suure tõenäosusega antud teemaga mingi isiklik suhe (kuid loomulikult võib vahel postituse avamist ajendada pelk uudishimu). Sotsiaalteadlane Klaus Janowitz kasutab Michel Maffesolile toetudes virtuaalsete kogukondade kohta terminit e-hõimud (e-tribes), mis viitab sarnasusele mingil konkreetsel geograafilisel territooriumil elavate hõimude rühmakuuluvuse dünaamikatega. E-hõimusid defineeritakse kui väga heterogeensete isikute võrgustikke, mida seob mingi ühine kirg või emotsioon, kusjuures sellised võrgustikud on väga muutuvad, sõltudes konkreetsest situatsioonist (vrd Janowitz 2009: 6). Selle liigituse kohaselt oleks siis painajast rääkivate foorumikasutajate siduv situatsioon painajakogemus ning siduv emotsioon painajahirm ja selle ületamine.

\section{Kogemuse defineerimise püüded}

Paljudel inimestel, kes painajafenomeni esmakordselt kogevad, puuduvad temaatilised eelteadmised või on need väga napid, seetõttu pöördutaksegi oma postituses otsesõnaliselt teiste foorumikasutajate poole abipalvega, et need aitaksid kogemuse defineerida ja lahti mõtestada. Kõige sagedamini kirjeldatakse foorumi teemapüstituses mina-vormis kogemust ning tavaliselt on see toimunud üsna hiljuti. Kõige vahetumad kogemuskirjeldused vaadeldud materjali hulgas olid üles kirjutatud kohe pärast voodist tõusmist, näiteks teemapüstitus pealkirja all "Painaja KIIRE":

Juhtus hetk tagasi selline asi. Magasin rahulikult ja unenäos ehmatas mind miski, tegin silmad lahti, kuid end liigutada ei suutnud. Kõrvad lõi lukku ning järjest valjemaks läks sahin-ragin, oli selline tunne, et pea plahvatab kohe. Oma mõttes tahtsin ma midagi karjuda, aga 
huuled ei liikunud ning mingit häält välja ei tulnud. Keset tuba hakkas mingi valgusallikas kiirgama (otse põranda seest), keset seda "valgust" kumas kellegi / millegi nägu ning siis kadus see kõik. Kõik see toimus ligi 20 sekundi vältel. See ei ole esimene kord! Millega tegemist on? Parawebi ei viitsinud kasutajat tegema hakata, niisiis postitan siia. Olen 14 (www. lapsemure.ee, kasutaja: külastaja, sept 2012).

Erinevalt vanematest muistenditest ja kogemusjuttudest, milles enamasti ollakse teadlik, millise üleloomuliku olendiga täpsemalt kokku puututi, on foorumipostituste üks põhiküsimus kogetu defineerimine. Mõnikord ei oska kogemuse kirjeldaja temaga toimunut üldse kuidagi nimetada, näiteks järgmises postituses:

Tahtsin küsida, kas keegi on selliste asjadega kunagi kokku puutunud. Kas üldse on sellised asjad olemas või on see öine illusioon. Olen kuulnud paarilt inimeselt reaalset ja kõhedust tekitavaid lugusid ja isegi ühel korral ise midagi taolist läbi elanud, kuid ei tea, kas see oli mingisugune hingamisraskus ja halb unenägu (kuigi see oli jube ja ärkasin lõpuks üleni higisena ja hingeldavana). Kas selle kohta on kuskil seletusi antud, mis oleks reaalselt mõistetavad. Siiani on mul jäänud mulje, et see on midagi müstilist.... (naistekas.delfi.ee/foorum, kasutaja: öö, nov 2009).

Sageli ollakse veendunud, et tegemist oli mingi üleloomuliku olendiga, kuid ei teata tema õiget nime või ei olda kindel oma defineerimiskatse õigsuses, näiteks kirjeldab üks perefoorumi anonüümne kasutaja unesnähtud poltergeisti (kirjelduses endas leiduv määratlus) tegevust ja küsib kirjelduse lõpuks: "Millega võis tegu olla? Üleväsimus kindlasti, aga kas tõesti luupainaja?” (perekool.ee, juuli 2012). Üldfoorumis naistekas.delfi.ee/foorum küsib kogemuse kirjeldaja: "Kas mul oli luupainaja?" Isegi foorumis Para-web.org, milles peamiselt vesteldakse paranormaalsetest nähtustest ja orienteerutakse üleloomuliku maailma mõistestikus paremini, kohtab sarnaseid küsimusi, näiteks postituses pealkirjaga: Kas need on luupainajad? (www.para-web.org, kasutaja: neiu, märts 2014).

\section{Juhtumianalüüs 1: painaja ühine defineerimine foorumis}

Näitejuhtumi teemaalgataja (naistekas.delfi.ee/foorum, kasutaja: esmakordne siin, dets 2009) ei püüa isegi oletada, kes või mis võis tema ema kogemuse põhjustada, kuid viitab siiski üleloomulikule sfäärile, pealkirjastades oma teemaalgatuse: "mis on selle müstilise kolli või vaimu nimi?" Sellele järgneb põhjalikum kogemusekirjeldus:

Vabandan, kui segaselt seletan, aga olen kuulnud, et kui inimene magades enam korraga liigutada ei saa, istuks nagu keegi teki peal. . 
see oli keegi..M-tähega tüüp? mingi vaim või müstiline olend või... nagu tahaks hinge kallale kippuda. kas saate aru, mida pü̈̈an seletada? mul emaga juba teist korda nii ja ühe sugulasega, kes seal majas ööbinud, oli sama jama. keegi nagu istuks öösel sul liikmete peal, sa ei saa midagi teha, oled üleval, aga liigutada ei saa. kes/mis see on?

mina ei tea neist asjust midagi, ema huvitavad a la "kolmanda planeedi saladused”, aga ka tema ei oska seda seletada.

ma NAGU OLEKS kuskilt kuulnud, et sihuke sell käib hingi röövimas või ma panen ikka totaalset pada praegu?

Esmapostitusele järgnevad mõned abisoovitused, kuid teemaalgataja kordab veel kord, et soovib siiski kõigepealt täpsustada, millega on üldse tegemist ja kas selle olendi nimi algab m-tähega. Järgneb mitmekümnest postitusest koosnev aheldefineerimine, mille käigus esitatakse muuhulgas arvamusi, et kogemuse tekitanud olend oli poltergeist, majavaim, kodukäija, mardus, sukuubus (sucubis), mitmel korral tuuakse välja ka meditsiinilise unehalvatuse võimalus, vahele pakub üks irooniline kasutaja, et olendi nimi oli monn. Esitatud pakkumistele sekundeerib teemaalgataja, kes lisab kirjeldatava kogemusega seostuvaid uusi detaile, kurtes, et pole õige nimetuseni ikka veel jõudnud:

praegu mõtlen kuidas otsida ja mismoodi sisestada otsitava "nime”, kui ma ei tea isegi, mida ma otsin. deemon, kes istub öösel tekil? tuleks vist 0 vastust... (kasutaja: esmakordne siin, dets 2009).

Kõige enam pakutakse postitustes välja luupainajat/painajat,järgnevas näitetekstis aga kombineeritakse painajat laiemalt Lääne-Euroopa kultuuris tuntud, kuid eesti pärimuses tundmatu sukuubuse ja inkuubuse traditsiooniga:

Minu meelest on see tekipeal istuja ja rõhuja just nimelt tavaline luupainaja. eesti folklooris. mul vaatab raamaturiiulist vastu näiteks "imesõrmus" kus eesti folkloor sees, neid raamatuid on palju. luupainaja on keegi paha (elav) inimene, kes ema kisuamas käib. kodukäia jälle surnud hing, kes minu teada võib ka sarnaselt luupainajale rinna peal rõhuda.[---] muudes maades on luupainajal oma nimi. igal pool isemoodi, vastavalt keelele ja kultuurile. luupainaja vasted võiksid olla näiteks incubis ja sucubis (skeptik, dets 2009).

Teemaalgataja tunneb nüüd lõpuks, et postitatu tema kirjeldatuga haakub ning hakkab uute teadmiste toel painajaks käija isikut kindlaks tegema: 
[---] oma mälust võin Sulle öelda, et ta [kahtlusalune sugulane] oli nõia nägu küll (klassikaline kahte lehte kammitud süsimust pikk juus, prill ja kuri ilme), aga MA EI TAHAKS USKUDA, ET SEE ON TEMA. JA ta ju elab veel! [---] kas töesti tema? ja miks? (dets 2009).

Paralleelselt püüab ta endiselt välja selgitada olendi õiget nime. Ridamisi jätkuvad argumendid ja selgitused, millega välistatakse inkuubus ja mardus ning jõutakse otsuseni, et tegemist oli siiski luupainajaga.

Lõpuks kirjutab üks juba varem kommenteerinud kasutaja:

mulle ei andnud see M-täht rahu... tegu on skandinaavia mütoloogilise luupainajaga (vaim, mitte päris inimene) ja see nimi on MARA. nii, et kõik õige, on küll M-tähega luupainaja olemas (kasutaja: skeptic, dets 2009).

Niisiis on eeltoodud väljavõte näide lõpetatud defineerimistsüklist. Muidugi ei ole postitajate interaktsioon sugugi alati nii sidus ja ühesuunaline, mõningad eriarvamused võivad paralleelselt püsida kuni teemaarenduse lõpuni. Enamasti aga annab teemaalgataja siiski mingil hetkel märku, et ta on suutnud oma kogemuse teiste postitajate kaasabil talle aktsepteeritaval viisil defineerida.

\section{Uudsed kombinatsioonid}

Ootuspäraselt kombineeruvad seletamispüüetes klassikalised painajakujutelmad moodsast meediast (nt õudusfilmid, arvutimängud) pärit uudsete tegelastega. Järgnevas näites ilmuvad luupainajad zombide ja vampiiride kujul, kohe teksti alguses on ka viide nende nägemuste võimalikule päritolule (õudusfilmid).

Mul oli kaks nädalat tagasi luupainajad. mingi nädal aega järjest :S Suht erinevad...need olid vist sellest et suht öösel vaatasin oudukaid. Ma olen ühe luupainajat juba kolm korda näinud ja ühte teist kaks korda:S See mida ma kolm korda näinud olen, seal olid zombid ja see mida ma kaks korda näinud olen, seal olid vampiirid ja inimeste teisikud. teises oli see vastik et tahtsin ühte lü̈̈a ja jalg liikus aegluubis ja siis see sirutas käsi minu poole ja ma ärkasin ülesse (www.para-web.org, kasutaja: J.L., juuli 2009).

Painaja ja tulnukate kombinatsioone esineb siiski suhteliselt vähe, kumbki pärimus tundub arenevat paralleelselt eraldi. Järgnevas näitetekstis väidab postitaja, et ta ei mõtle igapäevaselt tulnukatele, kuid sellegipoolest esineb tekstis väide, et tal on tulnukate foobia, seega on ta ootuspäraselt selleteemalise 
materjaliga siiski varem kokku puutunud ja oskab eelteadmiste põhjal eeldada ka luupainaja ilmumiskuju (must kogu). Painaja seostamine olnud või peagi saabuva pahandusega on aga vanemas pärimuses haruldane:

Mul on olnud ka paar kolm korda luupainaja. Aga kuna mul ilge tulnukate foobia (ma ei tea miks, ma isegi ei ole kindel kas nad olemas on), siis ma nägin selle nn musta kogu asemel enda voodi kõrval mustalt tulnuka kuju. Ja see ajas mu eriti pööraseks. Ja just paar päeva tagasi, mul ei olnud mingit luupainajat aga lihtsalt keset ööd ärkasin üles ja tundsin nagu keegi vaataks mind, tegin silmad lahti ja jälle mustalt tulnuka kuju. Ma ei tea, mis värk sellega ongi. Ma ei mõtle igapäevaselt tulnukatele või ei kujuta ette endale igast õudusi.

[Aa, ja ma olen kuulnud et luupainaja tuleb siis, kui Sul on olnud või on tulemas mingi suurem pahandus. Tean öelda, et mul vist isegi paar korda peale suur pahandust tuligi luupainaja.] (www.buduaar.ee, kasutaja: M.O., sept 2010).

Üks esoteeriliste teemade arutelufoorumis postitaja esitab tulnukate ja painajate vaheliste seoste kohta järgmise kultuurilise analüüsi:

Kui veel UFOdest midagi ei teatud, räägiti luupainajatest. Painaja tuli kas inimese või looma kujul ja hakkas magajat rõhuma. Inimene tundis ôhupuudust ja nagu väänaks keegi tema liikmeid. Inimene ei saanud mitte midagi teha, ainult ebamääraselt häälitseda ehk. Kui sai pahema jala väikest varvast liigutada, siis läks painaja ära.

Nii et nähtus ise on igivana, tõlgendus kaasajatub (tuulepesa.zzz.ee, kasutaja: vanasti, okt 2005).

See postitus haakub folklorist Thomas E. Bullardi poeetilises sõnastuses seisukohaga: "Lood tulnukate inimröövidest kõlavad nagu vanade üleloomulike kohtumispärimuste ümberjutustused. [---] Teadus võib olla küll vaimud ja nõiad meie uskumustest välja juurinud, kuid tühi koht täitus tulnukatega, kellel on samad funktsioonid. Vahetunud on ainult välised tunnused. Kõik vanad hirmud ja nendega toimetulemise psühholoogilised draamad näivad olevat leidnud tagasitee koju, kus nagu tavaliselt jutumaailmas luusivad öösiti ringi tundmatud" (Bullard 1989: 168). Seega tuleb pidada peamiseks põhjuseks, miks painajakujutelmad nii vanemas vormis kui uudsete kombinatsioonidena jätkuvalt ringlevad, asjaolu, et jätkuvad inimeste intensiivsed, kuid raskestiseletatavad öised kogemused.

Mõningal määral seostatakse tänapäevastes seletustes painajakogemust spiritismi harrastamisega, näiteks küsivad foorumikaaslased ühelt kogemuse kirjeldajalt, kas ta on tegelenud vaimude väljakutsumisega või püüdnud muul 
moel surnutega ühendust saada (naistekas.delfi.ee/foorum, kasutaja: viimasele, mai 2010), kuna see võib nende arvates põhjustada painajakogemust. Sama teemapüstituse all järgnev postitus aga seostab painaja ilmumist deemonitega: "Need on deemonid, kes just siis ründavad, kui keha kõige nõrgem, sest hing on unerännakul" (naistekas.delfi.ee/foorum, kasutaja: hm, mai 2010). Nii tulnukad, zombid kui ka deemonid on eesti pärimuses kanda kinnitanud alles viimastel kümnenditel, seega saab öelda, et muutused mütoloogias ja usundis avalduvad operatiivselt ka inimkogemuse avaldumis- ja verbaliseerimisvormides.

Tänapäevastele painajakogemustele on omane ka see, et need on antropotsentrilised, see tähendab, et erinevalt vanemast usundilisest pärimusest, mis rääkis sageli ka kariloomi ründavatest luupainajatest, kujutatakse foorumivestlustes ohvritena ainult inimesi. Nimetatud asjaolu võib olla vähemalt osaliselt tingitud sellest, et moodsas urbaniseerunud elukorralduses on kariloomade pidamine kaotanud oma tähtsuse, ent huvitaval kombel ei kujutata ka tänapäeval kodudes peetavaid lemmikloomi painaja rünnakute sihtmärgina.

Rohkem kui 90\% internetifoorumites esitatud kogemuskirjelduste kohaselt ilmuvad ka painajad ise inimkujul (võrreldes vanemate usundiliste juttudega, milles painajat võidi kujutada ka loomana (nt kass) või esemena (nt hang)). Painaja sugu kirjeldustes valdavalt välja ei tooda. Vaid mõnel korral on mainitud sõnaselgelt just mees- või naissoost painajaid, kuid siiski puudub tänapäevastes painajakirjeldustes peaaegu täielikult erootiline aspekt. Suhteliselt vähestes postitustes kirjeldatakse luupainajat pigem aistinguna, näiteks külma õhuna (naistekas.delfi.ee/foorum, kasutaja: S.E., nov 2012), sammude või muu liikumishäälena (www.buduaar.ee, kasutaja: belts, juuli 2012). Külmaaistingut kui märki painaja kohalolekust on mainitud paljudes foorumipostitustes (lisaks on seda tänapäevastes kummitusraamatutes ja -saadetes seostatud vaimude lähedaloluga), seevastu vanemates pärimustekstides seda aistingut seoses painajaga ei märgita.

\section{Kogemuse põhjuste seletused}

Peaaegu kõikides painajat käsitlevates foorumiteemades mainitakse paralleelselt unehalvatust ning teisi teaduslikke, meditsiinilisi ja ratsionaalseid põhjuseid (nt liiga kuum või umbne ruum, õudusfilmide või paranormaalseid teemasid käsitlevate saadete vaatamine enne magamaminekut). Korduvalt nimetavad foorumikasutajad televisiooniprogramme painajakogemuste ja ka nendega seostuva hirmu allikana või neile kaasaaitajana: 
Kardan minagi selliseid asju [---] kõiges selles on sü̈̈di venemaa selgeltnägijate saade.. varem siukest hirmu polnd (www.buduaar.ee, kasutaja: kätu, juuli 2012).

Nii mõnigi kord kombineeritakse maagilisi ja teaduslikke seletusi isegi üheainsa postituse raames, näiteks:

Teaduslikult võttes on see ikkagi une ja ärkveloleku vahepealne seisund, kus keha ei allu käsklustele (nagu ka und nähes ju enamasti ei tee kõike kehaga kaasa, mida unes teed: jooksed, hüppad jne jne) ja mille ajal inimene miskipärast tajub, et on ärkvel, samas võidakse tihti näha luupainajaid (nt et keegi on su toas, varastab su hinge jne). See, et seda teaduslikult teatud piirini seletada saab, ei tähenda muidugi automaatselt, et selle taga midagi muud ei VÕIKS olla (nt et keegi / miski tõepoolest on sel hetkel seal ja tahab sust midagi), see jääb ilmselt jälle uskumise valda, nagu ka kõik muu üleloomulik, kui ei tule just aega, mil neid asju on kuidagi teistmoodi ja lõplikult võimalik seletada (ja mil teadus saab ometi legitiimselt käed rüpe lasta ja alla anda). (https:// tahanteada.wordpress.com, postituse "Kas sina usud kummitustesse?" kommentaaris, kasutaja: K.L., dets 2013).

Ratsionaalselt püüavad kaaskasutajad seletada vahel isegi selliseid juhtumeid, kui mõni postitaja on enda sõnul maagilistest võtetest abi saanud, näiteks seletatakse loitsu mõju painaja tõrjumisel psühholoogiliste põhjustega (autosugestioon). Paaril korral on painaja tekke põhjusena nimetatud eelmisel päeval toimunud magnettormi, "mis äkki ajas meeled sassi" (www.buduaar. ee, kasutaja: J2, juuli 2012). Viimast võib pidada poolteaduslikuks seletuseks, sest isegi teadlased ei ole kindlal seisukohal selle suhtes, mil määral suudavad magnettormid inimtaju mõjustada. Ühtlasi on selline seletusviis omane moodsale painajakäsitlusele, vanemas traditsioonis seda ei esine.

Teaduslike ja mütoloogiliste painajaseletuste kooseksisteerimist tuli mõnevõrra siiski ette ka vanematel aegadel, näiteks ajakiri Athenean Mercury avaldas juba 17. sajandi lõpus painaja üleloomulikke ja tolle aja mõistes teaduslikke seletusi kombineeriva artikli, milles märgiti: "See mõjus mõlemal viisil, nii toorestest ja seedimata segudest pärinevatest aurudest, vere kuumenemisest, nagu pärast tõsist joomist, ja mitmetest teistest loomulikest viisidest tulenevalt, aga mõnikord tekitasid seda õigupoolest nõiad... Ajalugu on tulvil selliseid juhtumeid" (tsiteeritud Davies 2003: 190).

Teaduslikkusele apelleerivatest seletustest palju levinumad on foorumidiskussioonides siiski üleloomulikud põhjendused, ning on näha, et meditsiinilised 
selgitused ei suuda sageli kõrvaldada saadud kogemuse müstilist varjundit ega vabastada kogejat hirmust, nagu kinnitab ka järgmine postitus:

Yeah, ma näen hiiglaslikku musta kogu enda poole tulemas igakord, kui see pask juhtub. Ja ma faking kardan igakord, despite fucking knowing it's fucking science (www.lapsemure.ee, kasutaja: mars, sept 2012).

Kuigi vaatlesin võimalikult erinevate internetifoorumite materjali, ei täheldanud ma painajateemaliste vestluste dünaamikas foorumite lõikes olulisi erinevusi. Ainuke mõnevõrra ootuspärane erinevus ilmnes üldfoorumite ja spetsiaalsemalt paranormaalsetele kogemustele ja üldse esoteerilistele teemadele keskenduvate arutelufoorumite postituste võrdluses - nimelt oli tajutav, et viimaste kasutajad tunnevad end painajateema suhtes rohkem informeerituna. Nende postitustes kohtab rohkem nii Euroopa vanemast folkloorist pärit seletusi, viiteid nii möödunud sajandite kui nüüdisaegsele kirjandustraditsioonile (nt James Sprengeri ja Heinrich Krameri Nõiahaamrile, Carlos Castaneda raamatutele) kui ka tänapäevaseid esoteerilisi tõlgendusi (nt painajakogemuse põhjusena mainitakse biovampiire, Hartmanni geovõrgustiku peal magamist, mis nõrgestab biovälja ja võimaldab vaimolendite pealetungi). Samuti pakutakse nimetatud spetsiaalfoorumites välja suuremal hulgal profülaktilisi tõrjeviise, nagu talismanide, pühitsetud küünalde, spetsiaalsete energeetilise kaitse võtete või maagiliste märkide kasutamine. Vanemates usunditeadeteski tuntud pihlakat soovitatakse painaja vastu kõikides foorumites, ent mõnes parateemade foorumi postituses loetletakse lisaks terve rida teisigi vana pärimuse võtteid, näiteks:

Käed-jalad magades risti hoida. Särk-püksid ööseks pahupidi selga. Pihlakaoks padja või voodi alla. Enne magamaheitmist ristimärk toanurkadesse õhku ja viiendaks endale risti ette lü̈̈a (www.para-web.org, kasutaja: meenutaja, okt 2009).

Vaatamata kasutajate heale orienteerumisele painajavastaste kaitsevõtete vallas leidub vahel ka esoteerika- ja parafoorumites küsimusi ja kahtlusi, nagu näiteks:

Kas siis nagu ma mõistan võib luupainaja olla mõni tuttav inimene? Kas ka nii, et ta ise ei ole kursis, et ta kuidagi käib mind painamas? (www. para-web.org, kasutaja: topaas, dets 2012).

Kui üldfoorumites kirjeldatakse painajakogemust peaaegu eranditult negatiivsena, siis mõnes esoteerikafoorumi postituses oli sellele antud ka positiivne hinnang, tunnetades seda osana inimese vaimsest arengust ja tõlgendades kogemuse käigus ilmunud olendit ingli või heatahtliku tulnukana. 


\section{Foorumikasutajate suhtlusmudelid}

Jälgides konkreetsete teemaalgatuste kommenteerimist torkavad silma teatud korduvad dünaamikad: vastandumine ja vastastikune korrigeerimine, võtted oma väidete autoriteetsuse suurendamiseks jms.

\section{Juhtumianalüüs 2: foorumidialoogide mudelid}

Järgnev näide näitlikustab foorumikasutajate koostoimet kirjeldatava painajajuhtumi seletamisel. Pealkirja all "Keegi istub voodi äärel... vaim" esitab teemaalgataja oma kogemuse kirjelduse ja palub teistel kasutajatel aidata leida selle tähendus:

Tere! Eile tabas mind üks imelik juhtum ning minuga pole midagi sarnast varasemalt juhtunud. Vaatasin telekat, kui tundsin, et keegi nagu istuks voodi äärele teki peale, sest oli koheselt tunne, et kisuti tekki. Vaatasin, et see on kass, kes kõrvale mulle tulnud, kuid kui katsusin, polnud seal mitte kedagi, aga ikkagi keegi istus seal. Mida see võiks tähendada? Kas kellelgi veel sellist juhtumit olnud? (www.buduaar.ee, kasutaja: B.S., juuli 2012).

Järgneb rida postitusi erinevatelt foorumikasutajatelt, kuid ükski neist ei paista teemaalgatajat rahuldavat, seetõttu lisab ta mõne aja pärast eelmisi kommentaare ümberlükkava ja kogetut täpsustava kommentaari:

Mingit tumedat kogu ega vaimu ei näinud. Absoluutselt mitte midagi, lihtsalt tundsin, et sättis ilusasti istuma ennast. Hommikul esimese asjana kartsin, et vanaema suri või keegi, kuid siiamaani pole keegi helistanud ega teaks, et keegi surnud oleks. Tahtsingi lihtsalt küsida, et kuidas teistel olnud on. Kartsin, et äkki see tähendab, et nüüd keegi lähedane või ise hakkab surema või midagi muud halba. Aga hetkel on rohkem peas variant, et kadunud sõbranna tuli külla ja ootab surnuaeda meid. Täna lähme surnuaeda talle haua peale ka (www.buduaar.ee, kasutaja: B.S., juuli 2012).

Postitaja tõlgendab siin oma kogemust esmalt surmaende või halva endena, seejärel surnud inimese meeldetuletusena. Vanemas folklooris luupainaja surmaende funktsioonis ei esine, küll aga võivad peatsetele matustele lähikonnas viidata teised varjukujud (nt mardus), samuti ei tunne vanem painajapärimus seostamist surnud inimese edastatava sõnumiga. Seega tundub, et foorumikasutajal on passiivsed teadmised mitmest usundilisest kujutelmast, kuid aktiivse kasutuse puudumise tõttu on need hägustunud. 
Paralleelselt konkureerivate seletusversioonide esitamisega foorumis tõusetuvad autoriteediküsimused. Korduvalt tuuakse oma väidete paikapidavuse tõendusena välja isiklik üleloomulik kogemus. Näiteks üks kasutaja kombineerib vanemad painajauskumused tänapäevase biovampiirikujutelmaga, viidates isiklikult kogetule:

luupainajad tulevad siis kui su ümber on mingi inimene, kes annab sulle neg energiat või imeb sind energiast tühjaks...usu või ära usu, mul on kogemused olemas (www.buduaar.ee, kasutaja: kallu, sept 2010).

Nii mõnigi kord läheb vastandlike arusaamade kommenteerimine ühe postituse raames üle kahe üksteisele vastanduva foorumikasutaja vaheliseks dialoogivormis dispuudiks.

Kasutaja D.A. kommenteerib hiljutist postitust, milles kasutajanime Piimariiul all esinev postitaja väidab, et luupainaja, vaim ja unehalvatus on kõik sama asi, vastanduval moel:

Aga vot ei ole, sa veits vii end nende asjadega kurssi Kummitus on siiski sootuks teine asi, sa lihtsalt ei usu neisse ja seega panedki ühte patta (www. buduaar.ee, kasutaja: D.A., juuli 2012).

Järgneb Piimariiuli vastukäik, mida võib vaadelda juba üleloomulike kogemuste süsteemsema klassifitseerimiskatsena:

Mmm..kui inimene ärkab uneparalüüsi tõttu ja näeb suurt musta varju/kaabuga meest või halli mehikest või surnud sugulast kes temagaga telepaatiliselt suhtleb, siis kui palju see erineb $n n$. kummitusjuhtumitest?Pluss arvukad tunnistused poltergeisti-ning vaimukogemustest kus kirjeldatakse "halvavat külmatunnet", mis eranditult kaasneb nö teispoolsuse olendite külaskäikudega.

Seega võib vabalt need ühte patta panna, nimetus uneparalü̈s tuli sellest et inimesed üldjuhul öositi magavad. Aga kui mõni ei maga ja ikka juhtub,siis on see "vaim".

D.A. vastab kriitiliselt:

Ma lugesin su jutu läbi, aga eks meil ole erinevad allikad, uneparalü̈̈si ajal on HALLUTSINATSIOON ja see ei ole sama mis kummitus ja vaim. Poltergeist on kah midagi muud ja nad ei ilmuta ennast ainult öösel. On sul nendega kogemusi olnud? Tundub, et mitte. Aga vot minu tuttvatega on. Poltergeistidel ongi võime inimest halvata ja isegi temasse siseneda, aga see kui su aju ärkab ia ise oled REM unes ning koged midagi, siis see on HOOPIS midagi muud. 
Nagu näha, viitab D.A. oma väidetele kaalu lisada püüdes oma tuttavate kogemustele, millele ka Piimariiul sekundeerib oma argumentide toetuseks kahe väidete autoriteetsust kinnitava allika - isikliku kogemuse ja tuntud filmi sissetoomisega:

Ikka on kogemusi Nii unes kui ärkvel. Oled Sa näinud filmi "Connecticutis kummitab”? Film äärmusliku nekrofillia ning -mantia tagajärgedest. [---]

Seejärel tsiteerib D.A. omakorda veel telesaateid, mis ühtlasi annavad aimu, millised allikad tema teadmisi painajauskumuste kohta on mõjutanud:

Jah ma olen seda filmi näinud see on üks mu lemmikuid samuti ka Insidious.. Aga ma olen ka igast dokumentaale läbi uurinud ja puurinud ja tean nendest asjadest väga palju, sest olen üks kummituste fanaatik, ja siiski uneparalü̈̈s ja kummitusega kohtumine ei ole päris sama, kuid jah, need asjad võivad ka kattuda. Kas sa nt. oled vaadanud saadet "The haunted" ja "The haunting"? Siis peaksid kah teadma. Ja deemonid on just need, kellele meeldib rünnata une ajal, kui vaimudele see ei loe üldse, millal. Ja samuti, võivad su nn kogemused olla ka sellest liigsest ülemõtlemisest

Kuna Piimariiul oma väidetes oluliselt järele ei anna, lisab D.A. veelgi rohkem autoriteetseid allikaid, samuti süüdistab ta väitluse teist osapoolt ülemõtlemises. Seega käivituvad siin tüüpilised foorumirollid ehk mõlemad postitajad asuvad eksperdi rolli, avaldades kahtlusi teise osapoole pädevuses (vrd rollide ja rollikäitumise kohta foorumites: Hiiemäe 2008; Hiiemäe 2013).

Siiski leidub enamikus painajateemalistes foorumiaruteludes vähemalt mõningaid aspekte, mille suhtes suurem või väiksem hulk postitajaid jõuab ühele meelele. Seega on ka kõige vihasemaid vaidlusi sisaldavatel aruteludel vähemalt teatud ulatuses kogemuse tõlgendust homogeniseeriv ja kehtiva traditsiooni raamidesse sobitav mõju.

\section{Üleloomuliku ja ratsionaalse kokkupõrked}

Foorumipostituste puhul on väga sageli iseloomulik, et koos esmase kogemuskirjeldusega lisatakse selgitus, milles postitaja rõhutab, et ta on õigupoolest väga ratsionaalne inimene ega ole selliseid lugusid enne iseenda kogemuse ilmnemist kunagi tõsiselt võtnud, seega rõhutades, et anomaalset kogemust ei saa kindlasti panna kogeja eksituse või vääritimõistmise arvele. Kogemuse tõesuse deklareerimist kohe jutustuse alguses mainivad ka mitmed teised tä- 
napäevase jutustamise uurijad (nt Fialkova \& Jelenevskaja 2001). Järgmises tekstis tuleb selgelt esile normaalse ja normivälise kontrasti rõhutamine:

Eks me kõik ole kuulnud lugusid luupainajatest, kuid kui palju me neid jutte siis ikka oleme uskunud? Nii ka mina. Mäletan, et vanaema kunagi rääkis, kuidas tal öösiti luupainaja külas käivat, istub rinnal ega lase hingata... Pidasin neid jutte lihtsalt vana naise sonimiseks kuni ühel päeval muutus kõik (naistekas.delfi.ee/foorum, kasutaja: S.E., nov 2012).

Toodud näitetekstis tuleb muuhulgas ilmsiks ka asjaolu, et rääkija oli vaatamata mitteuskumisele painajateemalise pärimusega juba varem kokku puutunud, olles seega siiski selle mõjuväljas.

Suutmatus ühitada ratsionaalset maailmavaadet ja anomaalset, enamasti üleloomulikuna tõlgendatavat kogemust tekitab kogejates segadust, kuna füüsiliselt sedavõrd selgelt tajutud aistingut on raske argumenteerimisega ümber lükata. Ka järgmisest kommentaarist nähtub, et kogeja ei ürita oma kogemust teaduslike seletustega olematuks muuta, vaid tunneb end sunnituna oma kogemust uskuma: "Ma ei uskunud selliseid asju enne, kui mu endaga see eelmisel suvel juhtus” (www.perekool.ee, anonüümne kasutaja, juuli 2012). Viisidest, kuidas inimesed üritavad oma erakordseid või üleloomulikke kogemusi sõnastades neid normaliseerida ning tõestada, et nad on nendele vaatamata täiesti adekvaatsed, on kirjutanud Kirsi Hänninen, näiteks kinnitatakse temagi sõnul juttudes sageli sõnaselgelt, et jutustaja pole vaimuhaige, purjus, tajumuutvate ainete mõju all, nähtu pole hallutsinatsioon, kuna see oli nii selgelt tajutav jne (vrd Hänninen 2010: 3, 162 jj). Mitmete muude erakordsete kogemuste usutavuse tõestamisel kasutatav viitamine usaldusväärsetele kaaspealtnägijatele painajakogemuse korral ei toimi, sest painajat ei kogeta peaaegu kunagi mitmekesi.

Tihti leidub tekstides viiteid kogemuse kohutavusele (näiteks: "Ma ei ole elu sees nii kartnud nagu siis", "Kõige kohutavam kogemus minu elus üldse”). Lisaks sellele, et niisugused kogemused ongi kahtlemata hirmutavad, näib siin olevat mängus ka teatav stilistiline aspekt. Kogemuse koleduse rõhutamine suurendab selle tõeväärtust (midagi nii hullu lihtsalt ei ole võimalik endale ette kujutada), samuti võib edasirääkimisega kaasnev kuulajaskonna sekundaarne hirmutamine olla abiks kogemuse läbielamisega kaasnenud abitustunde vähendamisel. Vahel lisatakse kogemuse verbaliseerimisel objektiivselt kõlavaid mõõtühikuid, nagu "ma nägin teda lähemalt kui meetri kauguselt", "ma vaatasin pärast kella, kell oli üks". Selliste jutustamisvõtetega justkui ennetatakse kaaskasutajate võimalikku skeptitsismi või kirjeldatud kogemuse kahtluse alla seadmist (retoorilistest vahenditest, mida kasutatakse esitatava teksti usutavuse suurendamiseks, vt pikemalt Oring 2008, teaduslike või teaduslikult 
kõlavate argumentide kasutamisest samal eesmärgil vt Valk 2010). Folklorist Gillian Bennett märgib usundilistest juttudest rääkides, et narratiiv esitatakse vestlusena mõttelise või tegeliku oponendiga (vrd Bennett 1999: 124 jj). Tuleb märkida, et foorumivestlustes on skeptiliste häälte osakaal ka tegelikult suur. Kuigi ka vanemates muistendites leidub teiste inimeste uskumusi ümberlükkavaid argumente, sekkub painajateemalistes foorumivestlustes peaaegu alati mingil hetkel mõni skeptiline kasutaja, kes peab painajakogemusi haiguseks, neurootiliseks fantaasiaks või "vanarahva" väljamõeldiseks. Leidub huumori kaudu parastavaid, naljakspööravaid ja naeruvääristavaid kommentaare, nagu:

kutsu ghostbusters'id ei usu, et midagi hullu, äkki lihtsalt läbi une kujutasid ette vms ära liialt paanitse =) (www.buduaar.ee, kasutaja: hapukas, juuli 2012).

Seevastu abivõtete kirjeldamisel näib viitamine vanemale pärimusele kandvat just vastupidist funktsiooni - selle eesmärk on veenda foorumikaaslasi kirjeldatava vahendi usaldusväärsuses ja tõhususes, kuna seda kasutas juba "vanarahvas" (pikemalt vana pärimuse kasutamisest veenmisargumendina vt Howard 2013).

\begin{abstract}
Abi
Tänapäeva usundi üldine pluralism ja eklektilisus avaldub ka painajatõrje meetodites.

Huvitava seaduspärana on foorumiaruteludes täheldatav fenomen, et kui diskussiooni algul tuuakse välja mõni konkreetne soovitus painajast vabanemiseks, siis hakkab see sageli korduma kogu arutelu jooksul (näiteks soovitus kasutada kaitseks haaknõela, lugeda meieisapalvet, panna küünal põlema).
\end{abstract}

\title{
Juhtumianalüüs 3: abisoovituste korduvelemendid
}

Teemaalgataja küsib oma avapostituses: "mul käib juba pikemat aega luupainaja öösist. kuidas sellest vabaneda" (naistekas.delfi.ee/foorum, kasutaja: user 17, mai 2009). Talle antud foorumivastustes võib kohata mitmekülgset valikut erinevate ajastute ja mõttevoolude abivahenditest, kuid siiski joonistuvad välja mõned korduvad elemendid. Kahes soovituses palutakse abivajajal selgitusi lugeda M. J. Eiseni populaarteaduslikust raamatust Luupainaja. Arutused ja jutud luupainajast (1922/2002). See eesti painajapärimusest ülevaatlikku pilti pakkuv raamat ilmus 1922. aastal, kuid alates 2002. aastast on sellest olemas ka internetist 
hõlpsasti leitav elektrooniline versioon. Ka teiste painajat puudutavate teemaalgatuste all võis aeg-ajalt leida Eiseni raamatust kopeeritud painajateemaliste rahvajuttude terviktekste.

Teiseks korduvaks liiniks olid new age’i õpetuste stiilis kaitsemaagilised soovitused, näiteks:

Muretse omale voodi peatsisse jumalaema ikoon või tee omale magama heites mõttes kriidiring ümber ja mässi end metallkookoni sisse samuti mõttes ja ära karda, mõttel on suur jõud (kasutaja: user ff, mai 2009).

Üsna järjestikku olid kolm peaaegu ühesuguse sisuga soovitust panna haaknõel voodiriiete külge, kõigi kolme puhul oli ära toodud ka lühike memoraat, näitlikustamaks, et see võte oli soovitajaid endid tõepoolest aidanud. Neist kahel korral toodi ära ka soovituse päritolu: üks kasutaja väitis, et oli lugenud seda kusagilt juturaamatust, teine märkis, et sai soovituse oma naabrinaiselt, "kes kõike teadis ja kõiki aitas" (naabrinaise aadress oli lokaliseeritud ühele kindlale Tallinna tänavale). Vanemas eesti pärimuses on küll metallobjektid kaitsemaagiliste vahenditena hästi tuntud, kuid haaknõeltest on juttu harva. Küll aga on need tuntud tänapäevases vene pärimuses ja mõningates muid teemasid käsitlevates foorumipostitustes on märgitud neid kurja silma vastase abinõuna.

Lõpuks leidub sama teemaalgatuse all postitus kasutajalt Uriinia (mai 2009), kes on foorumis delfi.naistekas.ee/foorum tuntud oma parodeerivate kommentaaride poolest: "Kui ta sisistab ja kannab suurt seenekujulist baretti, siis aitab ainult see, kui panna tema käigutee peale kauss külma veega. Las komistab sisse..." On selge, et tegemist on libasoovitusega, mille eesmärk on kogu toimuvat arutelu naeruks panna, kuid soovitus sisaldab sellegipoolest elemente vanemast usundilisest pärimusest (vesi on traditsiooniliselt tuntud halba mõju neutraliseeriv aine ja veekaussi on voodi alla soovitatud panna ka vanema pärimuse painajatõrjes).

Nii ülalnimetatud kui ka mitme teise teemaalgatuse all torkab silma, et soovitatakse vaid potentsiaalselt kehtivaid rituaale, mida pole ise proovitud või mille mõjusse väidetavalt ise ei usuta, näiteks: "osta vene kirikust küünlaid ja käi elamine nendega läbi, pidavat puhastama- ise muidugi ei usu" (www. buduaar.ee, kasutaja: sitikas, juuli 2012). Viimase näiterepliigi puhul on huvitav kahe paralleelse diskursuse esinemine: ühelt poolt soovitatakse maagilist abivõtet ja teiselt poolt toonitatakse enda mitteuskumist selle tõhususse. Catharina Raudvere nimetab painajaga seotud pärimust vaadeldes selliseid tõrjetegevusi, mida muistendites detailideni kirjeldatakse, kuid mille puhul 
pole tõendatav, et neid tegelikkuses läbi viidi või et need aitasid, fiktiivseteks rituaalideks (Raudvere 1995: 56). Need muistendirituaalid väljendavad tema sõnul ohuolukorrast pääsemise ideaali, sest tagavad jutus alati soovitud tulemuse (vrd Raudvere 1995: 57).

Üks kõige sagedamini väljapakutavaid abivõtteid on palvete, mõnevõrra vähem ka loitsude lugemine. Nagu vanemas pärimuses, kordub ka foorumitekstides kõige sagedamini soovitus lugeda meieisapalvet või veelgi lühemalt, lausuda Jeesus Kristuse nime. Järgmisest näitetekstist selgub, et painaja jätkas ilmumist meieisapalvest ja piibli lähedalhoidmisest hoolimata, kuid kogeja järeldab, et piibel aitas sellegipoolest, sest uus kogemus oli vähem intensiivne.

No parimad asjad juhtuvad ikka minuga, täna öösel uuesti käis ta külas, seekord polnud nii õudne kui eelmine, kuid siiski, kes krt mind vihkab nii palju? Mu ema andis mulle piibli ka padja alla, kuna see aitab, isegi õhtul enne magama minekut otsisin meie isa palve üles ja lugesin seda, proovides lausa pähe õppida kuid siiski:S Teadupärast ju piibel pidi eemale hoidma, kuid millegi huvitava teooria järgi ta siiski sai mulle ligi, kuid polnud see mis enne, arvan et piibel siiski kuigipalju aitas, kuna see tundus tema üritamisena, mis ei kukkunud just kõige paremini välja, aga asja fakt seegi.:S (naistekas.delfi.ee/foorum, kasutaja: kogeja, veebr 2010).

On tähelepanuväärne, et palve lugemist kirjeldatakse pigem kui tehnilist abivahendit ning palve jõusse uskumine tundub olevat tähtsuselt sekundaarne, samuti ei peeta palve kasutamisel vajalikuks jumalasse uskumist. Soovitusi otseseks pöördumiseks jumala või Jeesuse poole postitustes peaaegu ei esine, küll aga mainitakse korduvalt kaitseingli appikutsumist, kellelt loodetakse painajat tekitavate deemonite minema ajamist. Usundilise rõhuasetuse kandumist ainujumalalt kaitseinglitele või muudele vaimolenditele tänapäeva usundilises pärimuses üldisemalt on maininud mitmed autorid (viiteid nendele vt Hiiemäe 2012).

Foorumipostitustes leidub ka täiesti unikaalseid loitsutekste, näiteks mainib üks kasutaja, et samal ajal, kui teda vaevas painaja, ilmus tema mõtetesse teadmata kohast loits: "Eosite aolite sal! Eosite aolite sal!" (naistekas. delfi.ee/ foorum, kasutaja: S.E., nov 2012). Pärast nimetatud loitsu lugemist kasutajal enda sõnul enam painajakogemusi olnud ei ole. Postitaja märgib ühtlasi, et ta küll ei tea sõnade tähendust, kuid tema kreeka keelt õppinud ema arvates võib see olla kreeka keel. Järgneb postitaja enda analüüs:

Nojah, kongus kreeka nina võis sellel jubedikul ju olla ka....aga mis pistmist on minul mingi kreeka onuga? Olin ma kunagi mingis elus kreeklane, et seda keelt äkki oskasin? 
Sõnu, millel pole kindlat tähendust või mida ei saa tõlkida, võib üsna sageli leida ka vanemast loitsupärimusest, kuid endaloodud loitsusõnad on siiski võrdlemisi harvad, sest loitsu mõju seostati just selle traditsioonilisuse ja äraproovitusega. Lisaks puutepunktidele vanema loitsupärimusega tuleb nimetatud foorumiarutelus esile paralleelide tõmbamine piibliga - nimelt seostatakse tundmatus keeles loitsu ilmumist kristlikus traditsioonis tuntud "keelte rääkimisega" ehk ootamatult tekkinud oskusega võõraid keeli vallata.

Järgmine loits aga on selgelt liigitatav tänapäevase new age’i mõjulise loitsutraditsiooni alla:

Teisalt (kuigi võib-olla ei usuta vaimsetesse asjadesse) siiski tasub kõigil, kes samas voodis magavad kindlameelselt läbi teha järgmise dekreedi lausumine; seda $3 x$ võimalikult asjalikult valju häälega välja Universumile lausudes (mis näitab, et ollakse kindlameelne oma soovis):

Jumala ning kogu Valguse ja Armastuse nimel, teatan ma nüüd, et kõik vanded, needused, kokkulepped, tõotused ning siirded, mis on tehtud kas mulle või minu poolt kas selles elus või mõnes teises, kas selles universumis või mõnes paralleelses, olgu nad mõjutanud millist iganes minu kehadest, tühistatakse nü̈̈d ja praegu ning muundatakse puhtaks energiaks. Ma käsin nü̈̈d, et inglid, kes on valitsenud ja valvanud neid vandeid, oleksid nüüdsest vabastatud oma kohustustest. MA OLEN TÄIESTI VABA! (www.para-web.org, kasutaja: A.H., sept 2009).

Loitsutekstile järgnenud postituse autor kiidab loitsu ja ütleb, et see meenutab talle kusagilt loetud hopi indiaanlaste palvet. Sarnaseid loitse ja õpetusi võib kohata paljudes tänapäevastes new age'i teemalistes tõlkeraamatutes, nende ühised komponendid on näiteks pöördumine jumala asemel universumi poole, inglite kujutamine vahtidena, kes jälgivad, et kõiki vandeid ja tõotusi täidetaks, paralleelmaailmad, puhas energia - samas ei esine ühtki nendest elementidest vanemas eesti rahvapärimuses.

Postitustest võib järeldada, et kuna painajakogemus on kogejatele füüsiliselt ebamugav ja emotsionaalselt kurnav, ollakse sageli valmis ära proovima ka selliseid abivõtteid, mida muudes olukordades ei kaalutakski. Isegi kui teistelt foorumikasutajatelt kuuldud pärimusliku ainese tõeväärtuse poolt- või vastuargumendid foorumis abiküsijat hetkel ei veennud, jääb passiivne teadmine inimese alateadvusse ja võib järgmises analoogses situatsioonis aktualiseeruda (vrd sarnane märkus seoses pereelu teemaliste foorumivestlustega: Reinaus 2008: 37). Ka see on joon, mille poolest foorumikogukonnad sarnanevad traditsioonilistele pärimuskogukondadele. 


\section{Kokkuvõtteks}

Painajapärimust puudutava foorumimaterjali valguses saab nõustuda kultuuri- ja kirjandusteadlase Susana Arroyo Redondoga, kes märgib, et vanad muistendid, kaitsesõnad, kurjad vaimud ja jumalused on arenenud samas rütmis nagu uued tehnoloogiad, ning interneti näol on neile avanenud privilegeeritud levikuplatvorm (2006: 2). Kuna painajakogemus on nii füüsiliselt kui ka vaimselt intensiivselt tajutav, on seda raske eirata. Seetõttu püüavad selle kogejad seda aktiivselt mõtestada ning on altid aktsepteerima ja katsetama ka uusi kaitsemeetodeid. Internetifoorumites toimuvad painajateemalised arutelud sisaldavad viiteid paljudele erinevatele usundi- ja kultuuritraditsioonidele (vanem eesti rahvapärimus, new age'i kirjandus, oudusfilmid, meditsiinilised seletused), mida kombineeritakse ühise foorumiarutelu käigus loovalt. Aruteludes osalejaid seob sarnane kogemus ja sellega kaasnevad emotsioonid, samuti teabevahetus ja dispuudid läbielatu määratlemise ja tõrjemeetodite teemal ning soov vabaneda kogemustest, mida peetakse normiväliseks ja haiglaslikuks - seega on foorumites asetleidvad suhtlusprotsessid paljuski võrreldavad klassikalistes pärimuskogukondades toimuvatega. Ent tänapäevaste painajakogemuste folkloriseerumise protsessi mõjutavad vanemates arhiivitekstides kajastuvatest tunduvalt motiivirohkemad ja multikultuursema taustaga seletusversioonid, samuti on suurem abivõtete variaablus (näiteks on lisandunud omaloomingulised loitsud ja muudest kultuuridest laenatud kaitseviisid). Kui arhiivitekstides avaldub enamasti jutustaja kindel arusaam sellest, milline olend täpselt mingi üleloomuliku kogemuse põhjustas, siis tänapäevastes foorumitekstides esineb rohkelt kõhklusi kogetu ja selle põhjuste defineerimisel. Erinevusi ilmnes ka painaja ilmumiskujus. Kui vanema pärimuse painaja võis ilmuda ka looma kujul, siis moodsa pärimuse painajat kujutatakse peaaegu eranditult antropomorfsena. Võis märgata, et kuigi foorumivestlustes korduvad paljud eesti vanemast pärimusest tuntud motiivid, tingib foorumivestluste spetsiifika uudse grupidünaamika (näiteks teatavad mudelid teistele kasutajatele vastandumisel). Erinevalt vanematest tekstidest on foorumiaruteludes paralleelselt esindatud moodsa teaduse ja meditsiini diskursus, kuid sellegipoolest on põhirõhk endist viisi maagilisel ja üleloomulikul painajapärimusel.

\section{Kommentaar}

1 Artikkel on seotud institutsionaalsete uurimistoetustega IUT22-5 ja IUT2-43. 


\section{Internetiallikad}

Perefoorum (http://www.perekool.ee - 9. veebruar 2015).

Parateemade foorum (http://www.para-web.org - 9. veebruar 2015).

Esoteerikafoorum (http://tuulepesa.zzz.ee - 9. veebruar 2015).

Nõustamisfoorum (http://www.lapsemure.ee - 9. veebruar 2015).

Naistefoorum (http://www.buduaar.ee - 9. veebruar 2015).

Üldfoorum (http://naistekas.delfi.ee/foorum - 9. veebruar 2015).

Blogi (https://tahanteada.wordpress.com - 9. veebruar 2015).

\section{Kirjandus}

Arroyo Redondo, Susana 2006. Magia y superstición en la era de Internet. Culturas Populares. Revista Electrónica 2, lk 1-43 (http://www.culturaspopulares.org/textos2/ articulos/arroyo.pdf - 9. veebruar 2015).

Bennett, Gillian 1999. Alas, poor ghost! Traditions of belief in story and discourse. Utah: Utah State University Press.

Bullard, Thomas E. 1989. UFO Abduction Reports: The Supernatural Kidnap Narrative Returns in Technological Guise. The Journal of American Folklore 102 (404) (aprilljuuni), lk 147-170 (doi: 10.2307/540677).

Davies, Owen 2003. The nightmare experience, sleep paralysis and witchcraft accusations. Folklore 114 (2) (august), lk 181-203 (doi: 10.1080/0015587032000104211).

Eisen, Matthias Johann 1922 [veebiväljaanne 2002]. Luupainaja. Arutused ja jutud luupainajast. Tallinn: Kool. Võrguteavik 2002. Tartu: Eesti Kirjandusmuuseum (http:// www.folklore.ee/rl/pubte/ee/vanad/eisen/luupainaja/sisu.html - 9. veebruar 2015).

Fialkova, Larisa \& Jelenevskaja, Maria N. 2001. Vaimud kübermaailmas. Interneti folkloorisaitide analüüs. VTK raamat (http://www.folklore.ee/seminar/fialkova3a.html 9. veebruar 2015).

Hiiemäe, Reet 2008. Strategien zur Bewältigung von Ängsten durch massenmediales Erzählen. Schmitt, Christoph (toim). Erzählkulturen im Medienwandel (Rostocker Band zur Volkskunde und Kulturgeschichte. Band 3). Münster: Waxmann, lk 245-254.

Hiiemäe, Reet 2012. Taevasest teenäitajast kommertsmaailma sõnumitoojaks: ingli stereotüübid tarbijareklaamides. Mäetagused 51, lk 113-128 (doi: 10.7592/MT2012.51. hiiemae).

Hiiemäe, Reet 2013. Rollid ja rollikäitumine interneti esoteerikafoorumites. Kõiva, Mare (toim). Maailm ja multitasking. Tartu: EKM Teaduskirjastus, lk 109-132.

Honko, Lauri 1998. Folklooriprotsess. Mäetagused 6, lk 56-84 (doi: 10.7592/MT1998.06. honko). 
Howard, Robert Glenn 2013. Vernacular Authority: Critically Engaging “Tradition”. Blank, Trevor J. \& Howard, Robert Glenn (toim). Tradition in the Twenty-First Century. Locating the Role of the Past in the Present. Colorado: University Press of Colorado, lk 72-99.

Hufford, David 1989. Terror that comes in the night. Philadelphia: University of Pennsylvania Press.

Hufford, David 2005. Sleep Paralysis as Spiritual Experience. Transcultural Psychiatry. Vol. 42 (1), lk 11-45 (doi: 10.1177/1363461505050709).

Hänninen, Kirsi 2010. The construction of self in Finnish first-person supernatural encounter narratives. (Dissertation.) The Ohio State University.

Janowitz, Klaus M. 2009. Netnographie - Ethnographische Methoden im Internet und posttraditionelle Vergemeinschaftungen. Ohly, Peter (toim). Tagungsband zur Wissensorganisation '09 "Wissen - Wissenschaft - Organisation", 12. Tagung der Deutschen ISKO International Society for Knowledge Organization, 19.-21.10.2009, Bonn. Bonn, lk 1-2.

Jones, Ernest M. 1931. On the Nightmare. International Psycho-Analytical Library 20. London: Hogarth Press.

Kirschenblatt-Kimblett, Barbara 1998. Folklore's Crisis. Journal of American Folklore 111, lk 281-327 (doi: 10.2307/541312).

Kõiva, Mare \& Vesik, Liisa. Contemporary Folklore, Internet and Communities at the beginning of the 21st Century. Kõiva, Mare (toim). Media and Folklore. Contemporary Folklore IV. Tartu 2009: ELM Scholarly Press, lk 97-117 (http://www.folklore.ee/rl/ pubte/ee/cf/cf4/CF4_Koiva_Vesik.pdf - 9. veebruar 2015).

McClelland, Bruce 2000. Online Orality: The Internet, Folklore, and Culture in Russia. Lengel, Laura B. (toim). Culture and Technology in New Europe: Civic Discourse in Transformation in Post-Communist Nations. Stamford, CT: Ablex, lk 179-191 (http:// www.academia.edu/1222548/Online_Orality_The_Internet_Folklore_and_Culture_in_ Russia - 9. veebruar 2015).

Ness, Robert C. 1978. The old hag phenomenon as sleep paralysis. A biocultural interpretation. Culture, Medicine and Psychiatry 2, lk 26-28 (doi: 10.1007/BF00052448).

Oring, Elliott 2008. Legendry and the rhetoric of truth. Journal of American Folklore 121 (480), lk 127-166 (doi: 10.2307/20487594).

Raudvere, Catharina 1995. Analogy Narratives and Fictive Rituals: Some Legends of the Mara in Scandinavian Folk Belief. Arv: Nordic Yearbook of Folklore 51. Uppsala: The Royal Gustavus Adolphus Academy, lk 11-62.

Reinaus, Reeli 2008. Pärimusliku ainese teke ja areng Perekoolis ning selle avaldumisvormid. Mäetagused 38, lk 33-54 (doi: 10.7592/MT2008.38.reinaus).

Valk, Ülo 2010. Folklore and Discourse: the Authority of Scientific Rhetoric, from State Atheism to New Spirituality. Lewis, James R. \& Hammer, Olav (toim). Handbook of Religion and the Authority of Science. Leiden: Brill, lk 847-866 (doi: 10.1163/ ej.9789004187917.i-924.253). 


\title{
Summary
}

\section{Sharing Nightmare Experience on Internet Forums}

\author{
Reet Hiiemäe
}

Keywords: belief, Internet folklore, lore community, narration, nightmare

The article focuses on sharing nightmare experience on Internet forums. The author discusses how people, who, as a rule, are not active carriers of a consistent nightmare lore, speak about this phenomenon, how and on the basis of which sources they define and interpret their experience, and which dynamics become manifest in solving ideological arguments. One of the objectives of the article is to find out if we could, in spite of the fact that nightmare forum users are rather random and with very different backgrounds, regard them as a lore community, who, in their interaction, verbalise and interpret an individual's experience as consistent with the existing tradition. Also, the material obtained from the forums is compared with older nightmare texts, in order to highlight the features inherent in present-day material.

In light of the forum material concerned with nightmare lore, we could agree with Susana Arroyo Redondo (2006: 2), researcher of culture and literature, who has stated that old legends, protective phrases, evil spirits and deities have evolved in the same rhythm as new technologies, and the Internet has provided them with a privileged circulation platform (Redondo 2006: 2). As nightmare experience is intensely perceptible both physically and mentally, it is hard to ignore. Discussions about nightmares on Internet forums abound in references to a number of different belief and cultural traditions (older Estonian folklore, New Age literature, horror movies, medical explanations), which are creatively combined within forum discussions. The discussants are connected by means of a similar experience and related emotions, as well as exchange of information and disputes about defining their experiences and protective measures, and the wish to free them from this experience, which is regarded as abnormal and morbid - so, communication processes on the forums can be compared to those occurring in classical lore communities. Yet, the folklorisation process of present-day nightmare experiences is influenced by explanation versions with many more motifs and a multicultural background, and the variability of helpful measures is much higher (for example, self-created incantations and protective measures borrowed from other cultures). Archival texts mainly reveal the narrator's firm understanding of what kind of being caused their supernatural experience, whereas present-day forum posts show ample hesitation in defining the experience and its causes. The shapes in which the nightmare appeared were also different. While in older lore the nightmare could have appeared in the shape of an animal, then the contemporary nightmare is almost exclusively depicted as anthropomorphic. It could be noted that even if many motifs known from older Estonian lore were repetitive in forum conversations, the specificity of forum conversations created a novel group dynamics (for instance, certain patterns in opposing other users). Unlike older texts, forum discussions present also parallel discourses of modern science and medicine; however, the main emphasis still lies on magical and supernatural nightmare experience. 